\title{
Potassium Reabsorption in the Proximal Tubule of the Dog Nephron*
}

\author{
John F. Watson $\dagger$ \\ (From the Department of Medicine, State University of New York at Buffalo, Buffalo, N. Y.)
}

Previous micropuncture studies $(1,2)$ have demonstrated that potassium is extensively reabsorbed in the proximal tubule under conditions in which the net excretion of potassium in the urine varies, supporting the hypothesis that major adjustments in the rate of potassium excretion occur in distal parts of the nephron (3). To further evaluate the reabsorptive process in the dog nephron, fractional reabsorption of potassium from the proximal tubule was studied by micropuncture techniques during reductions in glomerular filtration rate (GFR) produced by renal arterial constriction, during proximal tubular inhibition of sodium reabsorption produced by isotonic saline infusion $(4,5)$, and during stimulation of potassium secretion by potassium loading and acetazolamide administration.

\section{Methods}

Male and female mongrel dogs weighing between 9 and $18 \mathrm{~kg}$ were used as experimental animals. The dogs were anesthetized by the rapid injection of $200 \mathrm{mg}$ of thiopental sodium administered intravenously as a $2.5 \%$ solution in distilled water; small additional doses were administered from time to time to maintain the desired level of anesthesia. Indwelling catheters were inserted into the ureters through a suprapubic midline incision. Polyethylene catheters were also inserted into the foreleg veins and the femoral vein or artery for the administration of fluids and collection of blood. The left kidney (experimental) was exposed through a flank incision and prepared for micropuncture as previously reported (6). Methods of tubular fluid collection and identification were also similar to those previously reported (6).

In all experiments, 15-minute urine collection periods for the determination of inulin and potassium clearances

* Submitted for publication December 9, 1965 ; accepted May 18, 1966.

Supported by grant AM-07352-03 from the National Institute of Arthritis and Metabolic Diseases.

$\dagger$ Research Career Development Award 5-K3-AM13183-03.

Address requests for reprints to Dr. John F. Watson, Dept. of Medicine, Buffalo General Hospital, 100 High St., Buffalo, N. Y. 14203. were obtained while tubular fluid samples were being collected. After appropriate priming and sustaining infusions of inulin had been given, 30 minutes was allowed to elapse before collections were begun to insure stable concentrations of inulin in plasma. Venous or arterial blood was drawn at the midpoint of each period, and urine was collected through the ureteral catheters.

Four groups of dogs were studied: 1) normal hydropenia, 2) hydropenia with renal arterial constriction, 3) potassium loaded with acetazolamide administration, and 4) normal dogs undergoing isotonic saline diuresis. In the hydropenic group with renal arterial constriction, an adjustable rubber clamp was placed around the renal artery of the experimental kidney before its bifurcation. The renal artery was gradually constricted until there was an observable decrease in kidney tissue turgor, and urine flow was reduced by at least $50 \%$ as compared with the control kidney. Only those tubular fluid samples were used that were collected during clearance periods in which the GFR of the experimental kidney was $75 \%$ or less of the control kidney.

Potassium-loaded animals were fed a diet containing $20 \mathrm{~g}$ of $\mathrm{KCl}$ daily for 1 week before the study and infused with a $\mathrm{KCl}$ solution at the rate of $33 \mu \mathrm{Eq}$ per minute per $\mathrm{kg}$ throughout the experiment. In addition, the dogs were administered acetazolamide (5 mg per $\mathrm{kg}$ ) intravenously throughout the study as necessary to maintain urine $\mathrm{pH}$ alkaline. In these experiments, tubular fluid samples were collected for the determination of bicarbonate concentration as well as potassium and inulin. The tubule was entered first with a quinhydrone microelectrode, and 0.005 to $0.001 \mu 1$ of tubular fluid was collected directly into the electrode for the determination of $\mathrm{pH}$ as previously described (6). The tubule was then reentered through the same puncture site, and at least 0.05 $\mu 1$ of tubular fluid was collected for the determination of potassium and inulin concentrations.

In the saline-loaded dogs, three 10 - to 15 -minute control periods were collected during hydropenia. Then isotonic saline was administered at a rate of $20 \mathrm{ml}$ per minute for a total of $500 \mathrm{ml}$ and continued throughout the experiment at a rate of $12 \mathrm{ml}$ per minute. Tubular fluid and urine collections were begun after the dog had received $1,000 \mathrm{ml}$ of saline.

Inulin and potassium were determined in duplicate from the same sample of tubular fluid by methods previously described (1). Inulin in plasma and urine was determined by the macroanthrone method of Fuhr, Kaczmarczyk, and Krüttgen (7). Sodium and potassium in plasma 
JOHN F. WATSON

TABLE I

Data for normal dogs*

\begin{tabular}{|c|c|c|c|c|c|c|c|c|c|}
\hline \multirow[b]{2}{*}{ Exp. } & \multicolumn{2}{|c|}{ GFR } & \multirow[b]{2}{*}{$P_{K}$} & \multirow[b]{2}{*}{$\mathrm{TF} / \mathrm{PIn}_{\mathrm{n}}$} & \multirow[b]{2}{*}{$\mathrm{TF} / \mathrm{Pr}_{\mathrm{K}}$} & \multirow{2}{*}{$\begin{array}{l}\left(\mathrm{TF} / \mathrm{Pk}_{\mathrm{TK}}\right) / \\
\left(\mathrm{TF} / \mathrm{PII}_{\mathrm{In}}\right)\end{array}$} & \multirow{2}{*}{$\begin{array}{l}\text { Location in } \\
\text { proximal } \\
\text { tubule }\end{array}$} & \multicolumn{2}{|c|}{$\left(\mathrm{U} / \mathrm{P}_{\mathrm{K}}\right) /\left(\mathrm{U} / \mathrm{P}_{\mathrm{In}}\right)$} \\
\hline & $\bar{c}$ & $\mathrm{E}$ & & & & & & $\begin{array}{ll}\mathrm{C} \\
\end{array}$ & $E$ \\
\hline & \multicolumn{2}{|c|}{$m l / m i n$} & $m E q / L$ & & & & $m m$ & & \\
\hline \multirow[t]{5}{*}{1} & & & 3.3 & 2.52 & 1.11 & 0.44 & 4.0 & & \\
\hline & & & 3.2 & 2.91 & 0.96 & 0.33 & 8.0 & & \\
\hline & & & 3.8 & 3.08 & 1.14 & 0.37 & 8.3 & & \\
\hline & & & 3.3 & 3.07 & 1.29 & 0.42 & 7.0 & & \\
\hline & 20 & 16 & 3.4 & 2.40 & 1.15 & 0.48 & 6.8 & 0.20 & 0.16 \\
\hline \multirow[t]{5}{*}{2} & & & 3.1 & 2.05 & 1.64 & 0.80 & 4.0 & & \\
\hline & & & 3.1 & 2.07 & 0.89 & 0.43 & 7.0 & & \\
\hline & & & 3.3 & 2.50 & 1.45 & 0.58 & 4.0 & & \\
\hline & & & 3.3 & $\begin{array}{l}4.25 \\
3.17\end{array}$ & 1.36 & 0.32 & $\begin{array}{l}6.0 \\
55\end{array}$ & & \\
\hline & 22 & 24 & $\begin{array}{l}0.0 \\
3.2\end{array}$ & $\begin{array}{l}.11 \\
2.02\end{array}$ & $\begin{array}{l}1.20 \\
1.34\end{array}$ & 0.06 & $\begin{array}{l}.5 \\
3.3\end{array}$ & 0.32 & 0.18 \\
\hline \multirow[t]{6}{*}{3} & & & 3.6 & 2.47 & 1.36 & 0.55 & 6.0 & & \\
\hline & & & 3.3 & 1.86 & 1.67 & 0.90 & 1.1 & & \\
\hline & & & 3.6 & 2.42 & 1.28 & 0.53 & 7.0 & & \\
\hline & & & 3.4 & 1.60 & 1.28 & 0.80 & 4.2 & & \\
\hline & & & 3.4 & 1.26 & 0.96 & 0.76 & 2.4 & & \\
\hline & 36 & 31 & 3.9 & 2.77 & 0.94 & 0.34 & 8.3 & 0.15 & 0.15 \\
\hline \multirow[t]{4}{*}{4} & & & 3.2 & 1.38 & $\begin{array}{r}0.99 \\
0.87\end{array}$ & 0.72 & 3.2 & & \\
\hline & & & 3.6 & 1.77 & $\begin{array}{l}0.87 \\
0.77\end{array}$ & 0.44 & $\begin{array}{l}2.4 \\
2.0\end{array}$ & & \\
\hline & & & & 1.55 & & & & & \\
\hline & 31 & 28 & $\begin{array}{l}3.5 \\
3.5\end{array}$ & $\begin{array}{l}3.40 \\
3.40\end{array}$ & $\begin{array}{l}0.97 \\
1.06\end{array}$ & $\begin{array}{l}0.29 \\
0.30\end{array}$ & $\begin{array}{l}6.0 \\
8.0\end{array}$ & 0.10 & 0.17 \\
\hline & & & & & & & & & \\
\hline
\end{tabular}

* GFR = glomerular filtration rate; $\mathrm{C}=$ control kidney; $\mathrm{E}=$ experimental kidney; $\mathrm{TF} / \mathrm{P}_{\mathrm{I}_{\mathrm{u}}}$ and $\mathrm{TF} / \mathrm{P}_{\mathrm{K}}=$ tubular fluid to plasma inulin and potassium concentration ratios; $\left(\mathrm{U} / \mathrm{P}_{\mathbf{K}}\right) /\left(\mathrm{U} / \mathrm{P}_{\mathbf{I}_{\mathbf{n}}}\right)=$ fractional excretion of potassium.

TABLE II

Data for dogs with decreased GFR

\begin{tabular}{|c|c|c|c|c|c|c|c|c|c|}
\hline \multirow[b]{2}{*}{ Exp. } & \multicolumn{2}{|c|}{ GFR } & \multirow[b]{2}{*}{$\mathbf{P K}_{\mathrm{K}}$} & \multirow[b]{2}{*}{$\mathrm{TF} / \mathrm{PIn}_{\mathrm{In}}$} & \multirow[b]{2}{*}{$\mathrm{TF} / \mathrm{P}_{\mathrm{K}}$} & \multirow{2}{*}{$\begin{array}{l}\left(\mathrm{TF} / \mathrm{P}_{\mathrm{K}}\right) / \\
\left(\mathrm{TF} / \mathrm{P}_{\text {In }}\right)\end{array}$} & \multirow{2}{*}{$\begin{array}{l}\text { Location in } \\
\text { proximal } \\
\text { tubule }\end{array}$} & \multicolumn{2}{|c|}{$\left(\mathrm{U} / \mathbf{P}_{\mathbf{K}}\right) /\left(\mathrm{U} / \mathrm{P}_{\mathbf{I n}}\right)$} \\
\hline & $\mathrm{C}$ & $E$ & & & & & & $\mathrm{C}$ & $\mathrm{E}$ \\
\hline \multirow{6}{*}{1} & \multicolumn{2}{|c|}{$m l / \min$} & $m E q / L$ & & & & $m m$ & & \\
\hline & & & & & 1.13 & & 1.8 & & \\
\hline & & & 2.3 & 2.07 & 1.47 & 0.71 & 4.0 & & \\
\hline & & & 2.6 . & 2.05 & 1.23 & 0.60 & 4.0 & & \\
\hline & & & $\begin{array}{l}2.6 \\
3.0\end{array}$ & $\begin{array}{l}2.00 \\
120\end{array}$ & $\begin{array}{l}1.14 \\
0.96\end{array}$ & $\begin{array}{l}0.57 \\
080\end{array}$ & $\begin{array}{l}5.4 \\
3.4\end{array}$ & & \\
\hline & 14 & 6 & 2.6 & & 1.37 & & 8.7 & 0.08 & 0.09 \\
\hline \multirow[t]{5}{*}{3} & & & 3.9 & & 0.95 & & 8.2 & & \\
\hline & & & 3.5 & 2.47 & 1.21 & 0.49 & 6.6 & & \\
\hline & & & $\begin{array}{l}3.5 \\
3.8\end{array}$ & & $\begin{array}{l}1.24 \\
0.96\end{array}$ & & $\begin{array}{l}8.0 \\
9.2\end{array}$ & & \\
\hline & & & $\begin{array}{l}3.8 \\
3.6\end{array}$ & 3.84 & $\begin{array}{l}0.96 \\
0.95\end{array}$ & 0.25 & $\begin{array}{l}9.2 \\
2.0\end{array}$ & & \\
\hline & 32 & 8 & 3.4 & & 1.45 & & 7.0 & 0.67 & 0.84 \\
\hline \multirow[t]{6}{*}{5} & & & 4.1 & 1.52 & 1.05 & 0.69 & 4.6 & & \\
\hline & & & 3.9 & 1.80 & 1.28 & 0.71 & 2.8 & & \\
\hline & & & 3.9 & 1.61 & 1.00 & 0.62 & 4.0 & & \\
\hline & & & 3.9 & 1.63 & 0.85 & 0.52 & 4.0 & & \\
\hline & & & 3.7 & 2.24 & 1.01 & 0.45 & 7.8 & & \\
\hline & 32 & 13 & 3.9 & 2.31 & 0.97 & 0.42 & 6.0 & 0.28 & 0.14 \\
\hline \multirow[t]{4}{*}{6} & & & 3.8 & & 1.35 & & 5.2 & & \\
\hline & & & 4.5 & 1.37 & 1.12 & 0.82 & 3.0 & & \\
\hline & & & 4.1 & 3.19 & 1.02 & 0.32 & 9.5 & & \\
\hline & 35 & 18 & 4.1 & 1.90 & 0.95 & 0.50 & 7.0 & 0.43 & 0.20 \\
\hline
\end{tabular}


TABLE III

Data for saline-loaded dogs

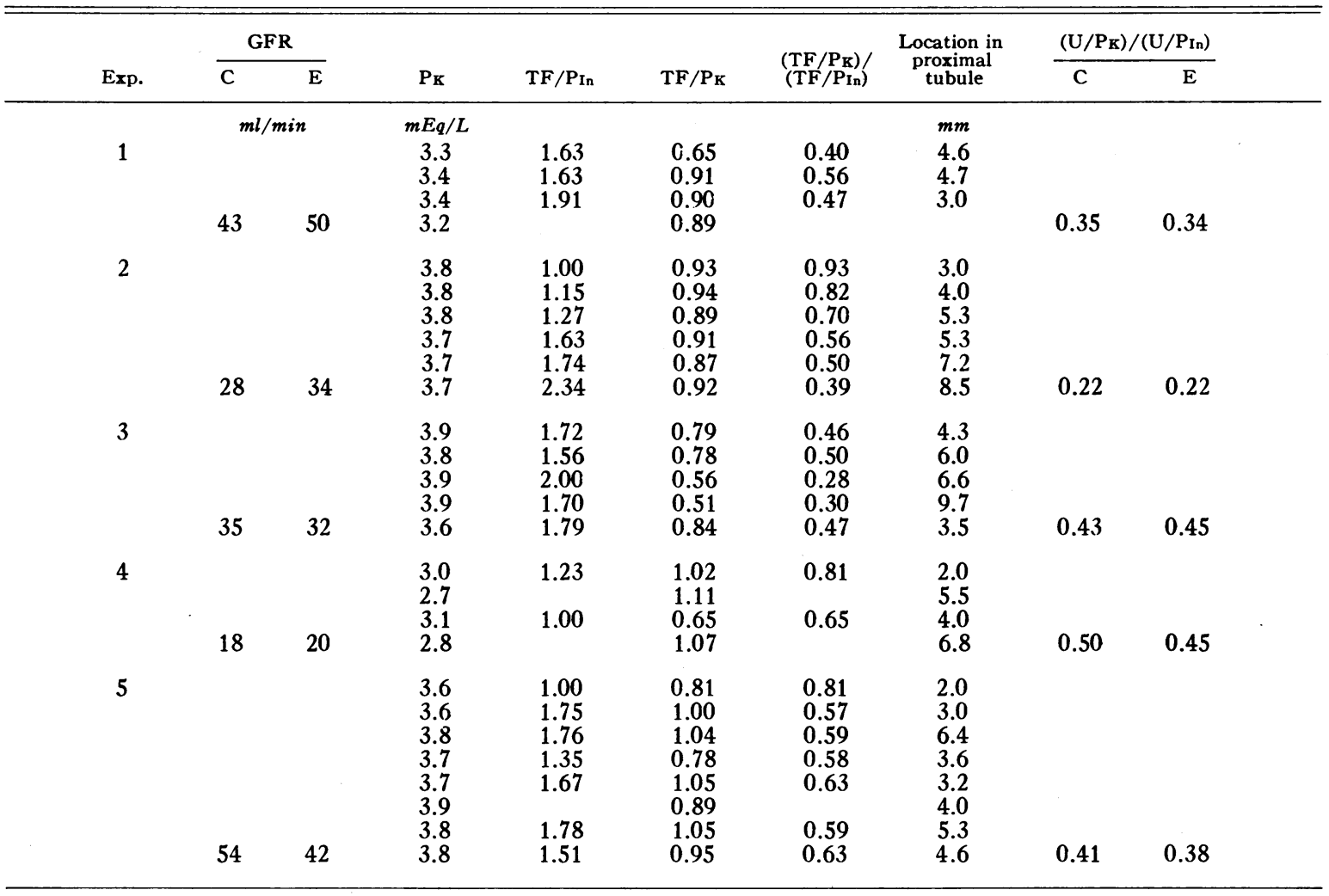

TABLE IV

Data for potassium-loaded, acetazolamide-infused dogs

\begin{tabular}{|c|c|c|c|c|c|c|c|c|c|c|c|c|}
\hline \multirow[b]{3}{*}{ Exp. } & \multirow{2}{*}{\multicolumn{2}{|c|}{ GFR }} & \multirow{3}{*}{$\frac{\text { Inulin }}{\text { TF/PIn }}$} & \multicolumn{3}{|c|}{ Potassium } & \multicolumn{3}{|c|}{ Bicarbonate } & \multirow{3}{*}{$\begin{array}{c}\text { Loca- } \\
\text { tion in } \\
\text { prox- } \\
\text { imal } \\
\text { tubule }\end{array}$} & \multicolumn{2}{|c|}{ Urine } \\
\hline & & & & \multirow[b]{2}{*}{$\mathbf{P K}_{\mathbf{K}}$} & \multirow[b]{2}{*}{$\mathrm{TF} / \mathrm{PK}_{\mathrm{K}}$} & \multirow{2}{*}{$\frac{T F / P_{K}}{T F / P_{I n}}$} & \multirow[b]{2}{*}{$\mathrm{PHCO}_{3}$} & \multirow[b]{2}{*}{$\mathrm{TF} / \mathrm{PHCO}_{3}$} & \multirow{2}{*}{$\frac{\mathrm{TF} / \mathrm{PHCO}_{3}}{\mathrm{TF} / \mathrm{P}_{\mathrm{In}}}$} & & \multirow[b]{2}{*}{$\mathrm{pH}$} & \multirow{2}{*}{$\frac{\mathrm{U} / \mathrm{P}_{\mathbf{K}}}{\mathrm{U} / \mathrm{P}_{\mathrm{In}}}$} \\
\hline & $\mathrm{C}$ & $E$ & & & & & & & & & & \\
\hline & \multicolumn{2}{|c|}{$m l / m i n$} & & $m E q / L$ & & & $m E q / L$ & & & $m m$ & & \\
\hline \multirow[t]{2}{*}{2} & & & & 5.1 & 1.34 & & 15.9 & 1.36 & & 8.5 & 7.76 & 1.18 \\
\hline & 23 & 19 & & 5.7 & 0.98 & & 18.5 & 1.28 & & 4.2 & 7.52 & 1.28 \\
\hline \multirow[t]{6}{*}{3} & & & 1.69 & 5.4 & 0.81 & 0.48 & 18.1 & 0.94 & 0.56 & 8.4 & 7.46 & 0.86 \\
\hline & & & 1.00 & 5.7 & 0.66 & 0.66 & 18.9 & 1.26 & 1.26 & 4.2 & 7.35 & 0.94 \\
\hline & & & 1.04 & 5.8 & 0.74 & 0.71 & 15.1 & 1.25 & 1.19 & 3.1 & 7.21 & 0.96 \\
\hline & & & 1.00 & 6.3 & 1.19 & 1.19 & 17.1 & 1.16 & 1.16 & 4.2 & 7.14 & 1.14 \\
\hline & & & 1.14 & 6.7 & 1.24 & 1.09 & 16.5 & 1.38 & 1.21 & 1.5 & 7.12 & 1.29 \\
\hline & 28 & 26 & 1.85 & 6.1 & 1.13 & 0.61 & 14.8 & 1.39 & 0.74 & 6.5 & 7.14 & 1.25 \\
\hline \multirow[t]{4}{*}{4} & & & 1.50 & 5.2 & 1.08 & 0.72 & 18.2 & 1.44 & 0.97 & 6.0 & 7.65 & 1.09 \\
\hline & & & 1.00 & 5.6 & 0.91 & 0.91 & & & & 3.2 & 7.60 & 1.00 \\
\hline & & & 1.37 & 5.1 & 1.19 & 0.89 & 18.1 & 0.81 & 0.61 & 3.3 & 7.58 & 1.13 \\
\hline & 44 & 39 & 1.20 & 5.2 & 1.30 & 1.08 & 18.0 & 1.10 & 0.92 & 4.5 & 7.52 & 1.18 \\
\hline \multirow[t]{4}{*}{5} & & & 2.02 & 4.2 & 1.17 & 0.58 & 24.4 & 2.09 & 1.04 & 7.2 & 7.89 & 1.14 \\
\hline & & & 2.51 & 5.4 & 0.99 & 0.39 & 22.9 & 2.23 & 0.89 & 8.4 & 7.86 & 1.05 \\
\hline & & & 1.83 & 4.9 & 0.95 & 0.52 & & & & 3.2 & 7.76 & 1.34 \\
\hline & 38 & 33 & 1.71 & 4.8 & 0.98 & 0.57 & & & & 3.8 & 7.70 & 1.31 \\
\hline 6 & 22 & 20 & 1.54 & 7.2 & 0.97 & 0.63 & 15.5 & 2.00 & 1.29 & 9.1 & 7.51 & 1.20 \\
\hline \multirow[t]{3}{*}{7} & & & 1.64 & 7.3 & 0.64 & 0.39 & 17.0 & 1.08 & 0.66 & 6.8 & 7.75 & 0.90 \\
\hline & & & 1.54 & 7.2 & 1.08 & 0.70 & & & & 1.6 & 7.75 & 0.88 \\
\hline & 29 & 28 & 1.60 & 7.5 & 0.72 & 0.45 & & & & 5.4 & 7.72 & 0.90 \\
\hline
\end{tabular}


and urine were determined with a Baird flame photometer, model KY-2. Tubular fluid bicarbonate concentration was calculated from the $\mathrm{pH}$ as determined by a quinhydrone microelectrode and the $\mathrm{PCO}_{2}$, with a $\mathrm{pK}$ of 6.13 , a solubility coefficient of $\mathrm{CO}_{2}$ in plasma of 0.03 mmole per $\mathrm{L}$ per $\mathrm{mm} \mathrm{Hg}$, and a $\mathrm{PCO}_{2}$ of $38 \mathrm{~mm} \mathrm{Hg}$. Arterial and urine $\mathrm{pH}$ were determined anaerobically at $37^{\circ} \mathrm{C}$ in a Beckman constant temperature $\mathrm{pH}$ meter. Plasma $\mathrm{CO}_{2}$ content was determined manometrically with a Natelson microgasometer. Donnan corrections were not made for filtered sodium. Standard statistical methods were used $(8)$.

\section{Results}

The relevant data from the four different experimental conditions are presented in Tables I to IV. In the latter portion of the proximal tubule, the tubular fluid to plasma inulin concentration ratios $\left(\mathrm{TF} / \mathrm{P}_{\mathrm{In}}\right)$ in the normal and decreased GFR groups were higher than in either the saline-loaded or potassium-loaded, acetazolamide-infused animals. All ratios except one were greater than 2.00 beyond $5.0 \mathrm{~mm}$ in the normal and decreased GFR experiments, whereas six and seven ratios were less than this figure in the potassium- and saline-loaded dogs, respectively No
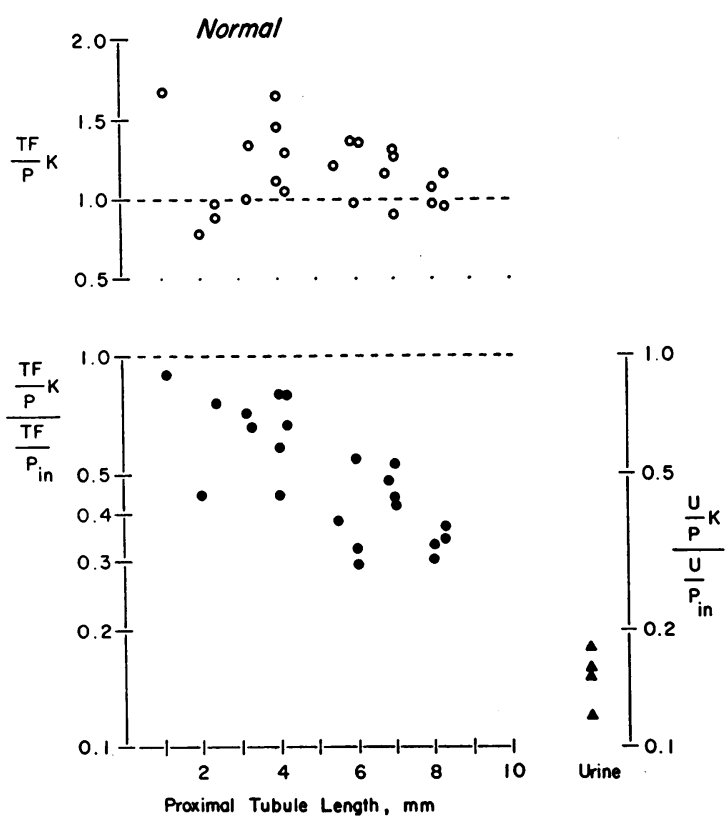

Fig. 1. Upper: Tubular fluid/Plasma potassium CONCENTRATION RATIOS EXPRESSED AS A FUNCTION OF ABSOLUTE DISTANCE FROM THE GLOMERULUS IN NORMAL HYDROPENIC DOGS. LOWER: POTASSIUM/InUlin CONCENTRATION RATIOS IN TUBULAR FLUID AND URINE OF NORMAL DOGS.
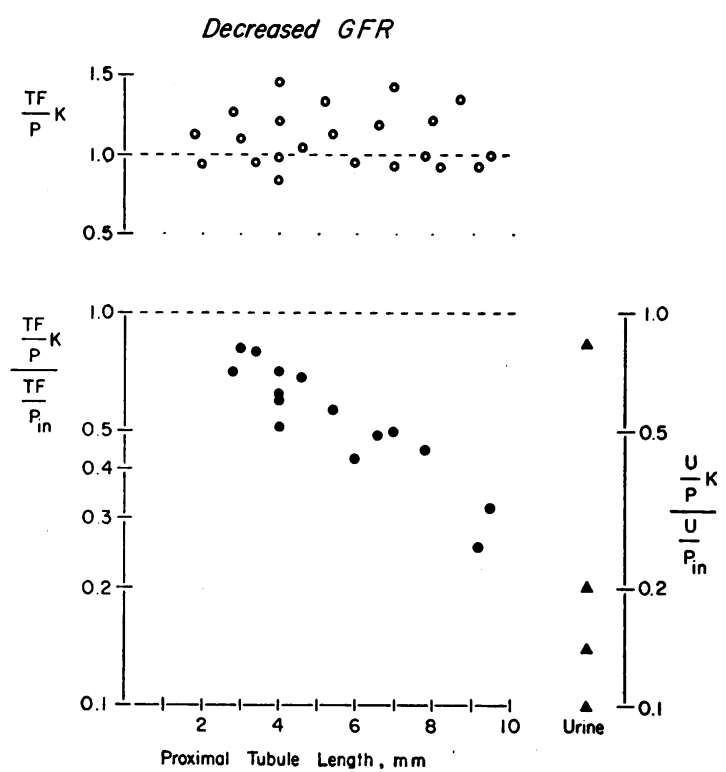

Fig. 2. Potassium and potassium/inulin CONCENTRATION RATIOS IN DOGS WITH DECREASED GLOMERULAR FILTRATION RATE (GFR).

statistical analysis of fractional water and sodium reabsorption under the different experimental conditions was made in this paper. Such a study is the subject of another report from this laboratory (5).

The plasma potassium concentrations were comparable in all the groups except the potassiumloaded animals, in which the values were elevated. The GFR from the experimental kidney was always $75 \%$ or more of the opposite control kidney in those groups other than the decreased GFR experiments, in which the filtration rates after renal arterial constriction ranged from 25 to $52 \%$ of the unconstricted control kidney. Fractional excretion of potassium $\left[\left(\mathrm{U} / \mathrm{P}_{\mathbf{K}}\right) /\left(\mathrm{U} / \mathrm{P}_{\mathrm{In}}\right)\right]$ varied over a wide range among the various conditions. Net secretion of potassium was evident in the potassium-loaded, acetazolamide-infused dogs and was distinctly higher than normal in the saline-loaded dogs.

In the potassium-loaded, acetazolamide infusion experiments, shown in Table IV, urine $\mathrm{pH}$ was alkaline in all samples. Tubular fluid bicarbonate concentration exceeded that of plasma in all but two samples. The fraction of filtered bicarbonate remaining $\left[\left(\mathrm{TF} / \mathrm{P}_{\mathrm{HCO}_{3}}\right) /\left(\mathrm{TF} / \mathrm{P}_{\mathrm{In}}\right)\right]$ at various distances along the proximal tubule was close to 
unity in the majority of samples, with a mean ratio of 0.96 .

The tubular fluid to plasma potassium concentration ratios $\left(T F / P_{K}\right)$ and the fraction of filtered potassium remaining in the tubule $\left[\left(\mathrm{TF} / \mathrm{P}_{\mathbf{K}}\right) /\right.$ $\left.\left(\mathrm{TF} / \mathrm{P}_{\mathrm{In}}\right)\right]$ for the four different conditions are plotted as a function of absolute distance from the glomerulus in Figures 1 to 4 . There was no relationship between the $T F / P_{K}$ ratios and position within the proximal tubule. The mean ratio of $1.16(\mathrm{SD} \pm 0.24)$ obtained from four normal hydropenic dogs was not significantly different from the mean ratio of 1.12 ( $\mathrm{SD} \pm$ 0.18 ) obtained from four dogs whose GFR was reduced by renal arterial constriction. The ratios from the six potassium-loaded, acetazolamide-infused dogs were slightly lower than those obtained in normal dogs, with the mean ratio of 1.00 ( $\mathrm{SD} \pm 0.21)$ being significantly different at the $95 \%$ confidence level. The ratios obtained (five dogs) during isotonic saline infusion were much lower, with the mean ratio of 0.88 ( $\mathrm{SD} \pm$ $0.15)$ being significantly less $(p<0.001)$ than that obtained from normal hydropenic dogs.

In spite of wide variations in the renal excretion of potassium, fractional reabsorption in the proximal tubule remained relatively constant with approximately $50 \%$ of the potassium reabsorbed by $6.0 \mathrm{~mm}$ of this segment of the nephron. Although net secretion of potassium was demonstrated in
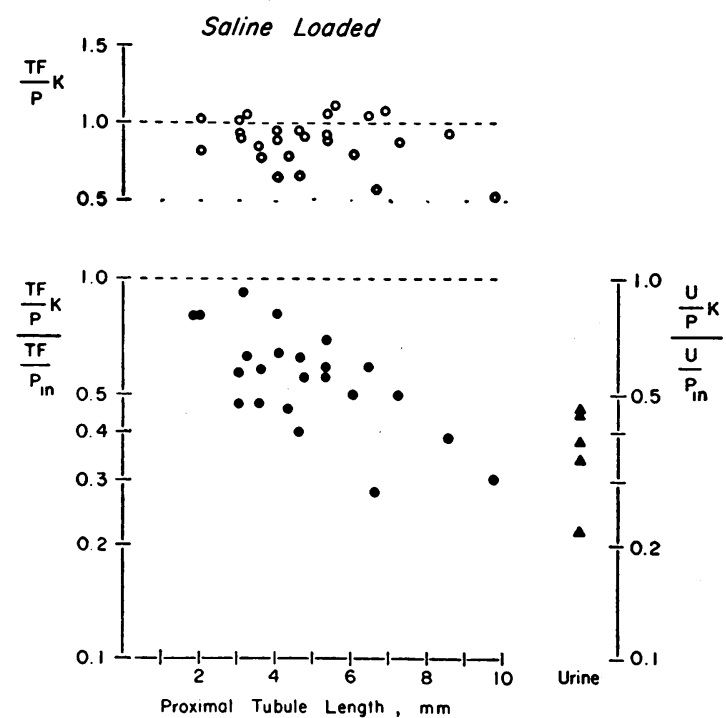

Fig. 3. Potassium and potassium/inulin ConcenTRATION RATIOS IN SALINE-LOADED DOGS.
TABLE V

Potassium and sodium excretion rates after isotonic saline infusion*

\begin{tabular}{|c|c|c|c|c|c|}
\hline Exp. & Protocol & $\underset{\mathbf{K}}{\text { Filtered }}$ & $\mathrm{UKV}_{\mathbf{K}}$ & $\begin{array}{l}\text { Filtered } \\
\mathrm{Na}\end{array}$ & $\mathrm{UNaV}_{\mathrm{Na}}$ \\
\hline & & $\underset{\min }{\mu E q /}$ & $\underset{\min }{\mu E q /}$ & $\min _{\min }$ & $\underset{\min }{\mu E q /}$ \\
\hline 1 & $\begin{array}{c}\mathrm{C} \dagger \\
\text { St } \\
\text { Changeई }\end{array}$ & $\begin{array}{r}258 \\
310 \\
+52\end{array}$ & $\begin{array}{r}31 \\
106 \\
+75\end{array}$ & $\begin{array}{r}11.11 \\
13.78 \\
+2.67\end{array}$ & $\begin{array}{r}30 \\
1,082 \\
+1,052\end{array}$ \\
\hline 2 & $\stackrel{\stackrel{\mathrm{C}}{\mathrm{S}}}{\text { Change }}$ & $\begin{array}{l}274 \\
231 \\
-43\end{array}$ & $\begin{array}{r}58 \\
72 \\
+14\end{array}$ & $\begin{array}{r}10.13 \\
9.66 \\
-0.47\end{array}$ & $\begin{array}{r}70 \\
686 \\
+616\end{array}$ \\
\hline 3 & $\stackrel{\stackrel{\text { C }}{\text { C }}}{\text { Change }}$ & $\begin{array}{r}232 \\
257 \\
+25\end{array}$ & $\begin{array}{r}60 \\
111 \\
+51\end{array}$ & $\begin{array}{r}7.40 \\
10.21 \\
+2.81\end{array}$ & $\begin{array}{r}51 \\
1,327 \\
+1,276\end{array}$ \\
\hline 4 & $\stackrel{\stackrel{C}{\mathrm{C}}}{\text { Change }}$ & $\begin{array}{r}157 \\
112 \\
-45\end{array}$ & $\begin{array}{r}17 \\
49 \\
+32\end{array}$ & $\begin{array}{r}6.83 \\
5.48 \\
-1.35\end{array}$ & $\begin{array}{r}40 \\
630 \\
+590\end{array}$ \\
\hline 5 & $\underset{\substack{\mathrm{C} \\
\text { Change }}}{\mathrm{C}}$ & $\begin{array}{r}236 \\
361 \\
+125\end{array}$ & $\begin{array}{r}114 \\
135 \\
+21\end{array}$ & $\begin{array}{r}9.49 \\
13.60 \\
+4.11\end{array}$ & $\begin{array}{r}183 \\
1,531 \\
+1,348\end{array}$ \\
\hline
\end{tabular}

* $\mathrm{UKV}_{\mathrm{K}}$ and $\mathrm{U}_{\mathrm{Na}} \mathrm{V}=$ urinary potassium and sodium excretion rates. + Mean of three 15-minute periods during hydropenia in control animals.

$\mp$ Mean of four to six periods during isotonic saline loading.

Mean of four to six periods during isotonic saline loading.
Absolute change between the control and saline-loaded periods

three of the samples obtained in the potassiumloaded, acetazolamide-infused dogs, covariance analysis of the regression coefficients did not reveal any significant difference among the four experimental conditions.

Table $\mathrm{V}$ illustrates the changes in sodium and potassium excretion rates after isotonic saline loading. The control figures (C) represent the aver-
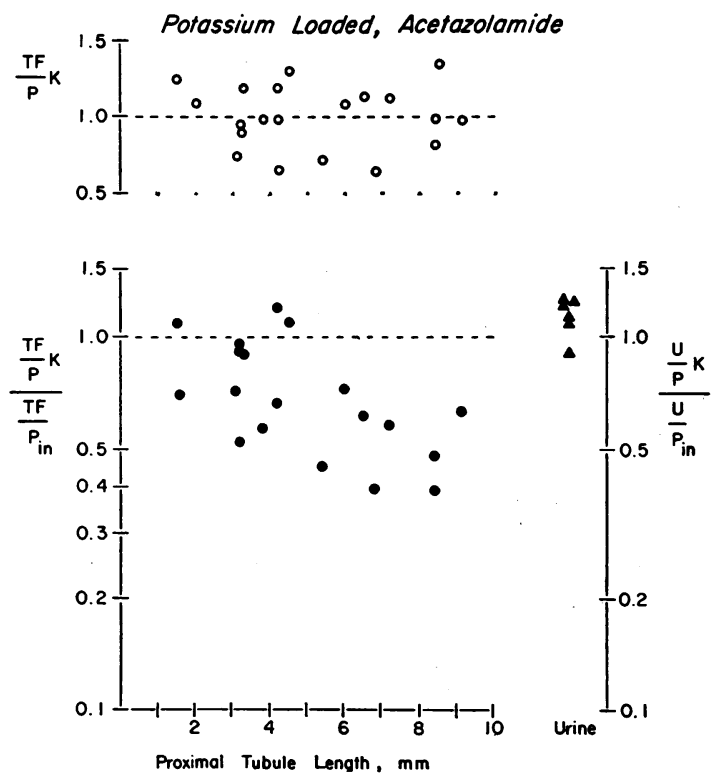

Fig. 4. Potassium and potassium/inulin concenTRATION RATIOS IN POTASSIUM-LOADED, ACETAZOLAMIDE-INFUSED DOGS. 
age of three 15-minute clearance periods during hydropenia. The saline-loaded values $(\mathrm{S})$ represent the mean of four to six 15-minute periods after the rapid infusion of isotonic saline. Potassium and sodium excretion rates increased in all experiments independent of changes in filtered load.

\section{Discussion}

The data in this paper are expressed as concentration ratio versus absolute distance from the glomerulus rather than the more conventional ratioper cent tubular length plot only for purposes of comparison and for technical reasons. It is not meant to imply that a ratio-distance plot more properly represents the relationship. The scatter in $\mathrm{TF} / \mathrm{P}_{\mathrm{In}}$ concentration ratios does not allow such a conclusion, since the relationship can be expressed with equal degrees of confidence by either method (5). A similar conclusion can be drawn from the data of Walker, Bott, Oliver, and MacDowell (9). Although the proximal tribule of the dog nephron varies between 9 and $24 \mathrm{~mm}$, the standard deviation about the mean $(15.1 \pm 3.3$ $\mathrm{mm}$ obtained from 40 dissections) is so small that any differences between the two types of plots may not be apparent (10).

The technical factors that make a ratio-distance plot more desirable are in regard to the measurement of tubular length. Straightening of the convoluted portion of the tubule is subject to variation depending on the extent to which it is stretched. In addition, the proximal tubule frequently ends in a gradual taper, thus compounding the error in measurement of total length. Most important, especially for comparative reasons, during saline loading when the tubule is distended, it is difficult to fill the entire proximal tubule with latex. On the other hand, measurement from collection site to glomerulus, even though the tubule is not adequately filled with latex, is reproducible and dependable.

Potassium is extensively reabsorbed in the proximal tubule. Furthermore, various maneuvers designed to increase net renal excretion of potassium do not alter the pattern of proximal tubular reabsorption $(1,2)$, implying that more distal segments of the nephron are responsible for the major adjustments in net renal excretion.

It has been proposed that all filtered potassium is reabsorbed proximal to the distal secretory site
(3). Since the pars recta of the proximal nephron is unavailable for sampling, an attempt was made to demonstrate enhanced potassium reabsorption in the accessible portion of the tubule in the presence of a decrease in glomerular filtration rate. As illustrated in Figures 1 and 2, the $T F / P_{K}$ ratios in the normal and decreased GFR experiments are similar and agree with previous studies of $\mathrm{TF} / \mathrm{P}_{\mathbf{K}}$ ratios in the normal nondiuretic $\operatorname{dog}(1)$. Furthermore, fractional reabsorption of potassium appears independent of filtration rate with some $70 \%$ of the filtered potassium being reabsorbed by $10.0 \mathrm{~mm}$ of the proximal tubule or by $66 \%$ of the average proximal tubular length, with an average proximal tubular length in dogs of $15.1 \mathrm{~mm}$ (10). This extent of fractional reabsorption of potassium agrees with results in rodents published by Malnic, Klose, and Giebisch (2).

There is conflicting evidence in the literature concerning the effect of alterations in filtration rate on fractional reabsorption of sodium and water. With $\mathrm{TF} / \mathrm{P}_{\text {In }}$ data, it has been observed that fractional reabsorption of sodium in rodents $(9,11)$ and dogs (4) is independent of filtration rate. A recent report from our laboratory (5) in normal and saline-loaded dogs supports this conclusion. On the other hand, Gertz, Mangos, Braun, and Pagel (12) using different techniques have presented evidence which suggests that fractional reabsorption of sodium increases when filtration rate is reduced. Since the $T F / P_{K}$ ratios are unequivocally the same in normal and decreased GFR experiments, the effect of alterations in filtration rate on fractional reabsorption of potassium will depend upon the interpretation of the relationship between fractional water reabsorption and GFR. This study supports the concept of glomerular tubular balance and furthermore indicates that whatever mechanism or mechanisms are responsible for this delicate relationship must be operative for solutes that are not necessarily linked in their transport out of the proximal tubular lumen (see below).

Potassium secretion is dependent on the availability of sodium at the distal secretory site (3); however, the relationship between sodium and potassium transport at the proximal reabsorptive site for potassium has not been investigated. Isotonic volume expansion by saline infusion inhibits sodium reabsorption in the proximal tubule $(4,5$, 
13). This is also evident in the low $T F / P_{\text {In }}$ ratios in Table III. However, isotonic volume expansion reduces the $T F / P_{\mathbf{K}}$ concentration ratios without altering fractional reabsorption. Thus the fall in $\mathrm{TF} / \mathrm{P}_{\mathbf{K}}$ ratios is the result of continued potassium reabsorption in the face of depressed sodium and water reabsorption. Under these conditions sodium and potassium reabsorption in the proximal tubule can be shown to be independent.

Potassium excretion in the urine increases after saline infusion when compared with the preloaded periods, but fractional reabsorption of potassium in the proximal tubule is unchanged. The increase in potassium excretion, therefore, must be derived from segments distal to the accessible portions of the proximal tubule. Since potassium secretion depends on the availability of sodium at the secretory site, the enhanced potassium excretion after saline loading may be the result of increased delivery of sodium to the distal secretory site as a result of proximal rejection with subsequent sodium for potassium exchange. Similar conclusions were made by Rector, Van Giesen, Kiil, and Seldin (14) during hypotonic saline infusion.

In previous micropuncture experiments concerning potassium reabsorption in the proximal tubule of the dog nephron (1), there was a suggestion that fractional reabsorption of potassium from the proximal tubule was decreased during potassium loading when compared to normals. This raised the possibility that some potassium may escape reabsorption in the proximal tubule under certain circumstances. The observation that an inverse relationship exists between potassium excretion and urinary acidification led to the proposal that potassium and hydrogen ions compete for secretion (15). TF $/ \mathrm{P}_{\mathbf{K}}$ and $\mathrm{TF} / \mathrm{P}_{\text {In }}$ ratios were determined in potassium-loaded dogs receiving acetazolamide in an attempt to demonstrate a change in potassium reabsorption in the proximal tubule. In addition, $\mathrm{TF} / \mathrm{P}_{\mathrm{HCO}_{3}}$ ratios were also determined to evaluate the extent of inhibition of hydrogen ion secretion. The $\mathrm{TF} / \mathrm{P}_{\mathbf{K}}$ ratios are slightly lower than those observed in hydropenic dogs, but fractional reabsorption of potassium is unchanged, indicating that the modest depression in the $T F / P_{K}$ ratios is secondary to depression of sodium and water reabsorption.

It is evident that inhibition of proximal tubular hydrogen ion secretion was achieved in this study, since all but two $\mathrm{TF} / \mathrm{P}_{\mathrm{HCO}_{3}}$ concentration ratios are greater than 1.00. Complete inhibition of bicarbonate reabsorption, however, was not achieved in all the samples, since the fraction of filtered bicarbonate remaining in the proximal tubule is less than $100 \%$ in five samples. Nevertheless, the majority of values are close to unity, and the mean ratio is 0.96 , implying that a major fraction of filtered bicarbonate escapes reabsorption in the proximal tubule under these conditions.

These findings of proximal inhibition of sodium reabsorption coupled with inhibition of hydrogen ion secretion are compatible with the concept of a hydrogen for sodium ion exchange. Potassium reabsorption in the proximal tubule is unaffected by inhibition of hydrogen ion secretion, whereas net potassium secretion in the final urine is evident. The proximal tubule, therefore, unlike the distal tubule, does not demonstrate a reciprocal relationship between hydrogen and potassium ion secretion. These results confirm similar observations made in rodents $(2,16)$.

These conclusions agree with the proposed model of the proximal tubular cell of the mammalian nephron as outlined by Giebisch (17). The active transport site for potassium appears to be located at the luminal membrane, whereas sodium is considered to move passively across this surface with its active transport site located on the contraluminal border. Net transfer of potassium into the tubular lumen may depend upon the electrochemical environment (2). The distal tubule, being considerably more negative to extracellular fluid than the proximal tubule (18), allows potassium to passively diffuse into the lumen at this site (2), whereas in the proximal tubule net movement of potassium into the lumen is limited. In the proximal tubule, therefore, net movement of potassium is always out of the lumen regardless of the rate of sodium and hydrogen ion transport.

The dissociation of sodium and potassium transport in the proximal tubule on the one hand, and the constant relationship between filtered load and fractional reabsorption for both ions on the other, suggest that physical factors rather than humoral are responsible for glomerular tubular balance. Conversely, continued potassium reabsorption in the face of inhibited sodium reabsorption favors a specific (possibly humoral) effect on the active 
transport site for sodium during volume expansion by isotonic saline loading.

\section{Summary}

Proximal tubular fluid to plasma potassium and inulin ratios were determined in four different experimental conditions: 1) hydropenia, 2) hydropenia with renal arterial constriction, 3) potassium loading with acetazolamide administration, and 4) isotonic saline loading.

The mean tubular fluid to plasma potassium concentration ratio was 1.16 in normal hydropenic dogs, 1.12 in hydropenic dogs with reduced glomerular filtration rate produced by renal arterial constriction, 1.00 in potassium-loaded dogs receiving acetazolamide, and 0.88 during saline loading. Fractional reabsorption of potassium in the proximal tubule was independent of filtration rate and not affected by either inhibition of proximal tubular sodium reabsorption or inhibition of hydrogen ion secretion. Inhibition of proximal tubular hydrogen ion secretion in the potassium-loaded dog depressed sodium reabsorption in this segment. The results further support the concept that potassium is extensively reabsorbed in the proximal tubule and that nephron segments more distal than the accessible portions of the proximal tubule are responsible for adjustments in the rate of potassium excretion.

\section{References}

1. Watson, J. F., J. R. Clapp, and R. W. Berliner. Micropuncture study of potassium concentration in proximal tubule of dog, rat, and Necturus. J. clin. Invest. 1964, 43, 595.

2. Malnic, G., R. M. Klose, and G. Giebisch. Micropuncture study of renal potassium excretion in the rat. Amer. J. Physiol. 1964, 206, 674.

3. Berliner, R. W. Renal mechanisms for potassium excretion. Harvey Lect. 1959-60 (series 55), 141.

4. Dirks, J. H., W. J. Cirksena, and R. W. Berliner. The effect of saline infusion on sodium reabsorption by the proximal tubule of the dog. J. clin. Invest. $1965,44,1160$.
5. Watson, J. F. Effect of saline loading on sodium reabsorption in the dog proximal tubule. Amer. J. Physiol. 1966, 210, 781.

6. Clapp, J. R., J. F. Watson, and R. W. Berliner. Osmolality, bicarbonate concentration, and water reabsorption in proximal tubule of the dog nephron. Amer. J. Physiol. 1963, 205, 273.

7. Fuhr, J., J. Kaczmarczyk, and C. D. Krüttgen. Eine einfache colorimetrische Methode zur Inulinbestimmung für Nieren-Clearance-Untersuchungen bei Stoffwechselgesunden und Diabetikern. Klin. Wschr. 1955, 33, 729.

8. Snedecor, G. W. Statistical Methods. Ames, Iowa State University Press, 1964, p. 394.

9. Walker, A. M., P. A. Bott, J. Oliver, and M. C. MacDowell. The collection and analysis of fluid from single nephrons of the mammalian kidney. Amer. J. Physiol. 1941, 134, 580.

10. Watson, J. F. Unpublished observation.

11. Giebisch, G., and E. E. Windhager. Renal tubular transfer of sodium, chloride and potassium. Amer. J. Med. 1964, 36, 643.

12. Gertz, K. H., J. A. Mangos, G. Braun, and H. D. Pagel. On the glomerular tubular balance in the rat kidney. Pflügers Arch. ges. Physiol. 1965, 285, 360.

13. Cortney, M. A., M. Mylle, W. E. Lassiter, and C. W. Gottschalk. Renal tubular transport of water, solute, and PAH in rats loaded with isotonic saline. Amer. J. Physiol. 1965, 209, 1199.

14. Rector, F. C., G. Van Giesen, F. Kiil, and D. W. Seldin. Influence of expansion of extracellular volume on tubular reabsorption of sodium independent of changes in glomerular filtration rate and aldosterone activity. J. clin. Invest. 1964, 43, 341.

15. Berliner, R. W., T. J. Kennedy, Jr., and J. Orloff. Relationship between acidification of the urine and potassium metabolism. Amer. J. Med. 1951, $11,274$.

16. Clapp, J. R., J. F. Watson, and R. W. Berliner. Effect of carbonic anhydrase inhibition on proximal tubular bicarbonate reabsorption. Amer. J. Physiol. 1963, 205, 693.

17. Giebisch, G. Measurements of electrical potentials and ion fluxes on single renal tubules. Circulation 1960, 21, 879.

18. Clapp, J. R., F. C. Rector, Jr., and D. W. Seldin. Effect of unreabsorbed anions on proximal and distal transtubular potentials in rats. Amer. J. Physiol. 1962, 202, 781. 